\title{
Neslihan'ın Anısına
}

\section{To Memory of Neslihan}

\section{Sibel Kartal ${ }^{*}$}

$\ddot{\boldsymbol{O}} z$

Sevgili mesai arkadaşım ve dostum Neslihan'ın vefatı nedeniyle kaleme aldığım anı yazısıdır. Anahtar Sözcükler: Neslihan Güler; Türk kütüphaneciliği; Hazine ve Maliye Bakanlı̆̆ Kütüphanesi.

\section{Abstract}

This is a memoir that I wrote due to the death of my dear collegue and friend Neslihan. Keywords: Neslihan Güler; Turkish librarianship; Library of Treasury and Finance Ministry.

Hazine ve Dış Ticaret Müsteşarlığı kütüphanesine nakil yoluyla geldiğimde Neslihan arkadaşım yeni kurulacak kütüphanede göreve başlamıştı. Daha sonra aramıza başka bir meslektaşımız daha katıldı. Biz aynı ekolden gelmiş üç kütüphaneci yeni bir oluşum için bir aradaydık. Neslihan Milli Kütüphane, ben ODTÜ ve diğer arkadaşım İGEME kütüphanesi’nde çalışmıştı. Genç olsak da daha önce çalıştı̆̆ımız yerlerde ve okul hayatının edindirdiği tecrübelerle kütüphane kurma yolunda bir araya geldiğimizde yirmili yaşlarımızdaydık .

Üç arkadaş birbirimizi yeni tanımanın verdiği heyecan ile sıfırdan bir kütüphane kurma yolunda kamu kurum kütüphanelerinin işleyiş ve yapılarını, hizmet anlayışını, kurumun beklentilerini belirlemeye çalışarak büyük bir çalışma içine girmiştik. Kütüphane kurulurken bizden beklenen otomasyon sistemi ile başlangıç yapılmasıydı. Hepimiz daha önce deneyimlememiş olmamıza rağmen Bliss Kütüphane Otomasyon sisteminde tüm yayınları bilgisayara aktarmaya çalıştık. Artık sistem kurulmuş bizler birbirimize daha da yakınlaşmaya başlamıştık.

Neslihan grup çalışmalarımızda, bireysel çalışmalarımızda ve bilgisayar ile çalışmalarımızda hep sakinliğini korur verimli, katılımcı tavır sergileyerek ortamda hoş bir hava oluştururdu.

Neslihan yıllar geçtikçe benim için iş arkadaşlığından öte hoşgörüsü, neşesi, yardımseverliği, pozitifliği ile can arkadaşım, dostum, sırdaşım oldu.

\footnotetext{
* Hazine ve Maliye Bakanlığı Ekonomik Programlar ve Araştırmalar Genel Müdürlüğü, Ankara, Türkiye. Eposta: kartalsibel2011@gmail.com

Ministry of Traesury and Finance General Directorate of Economic Programs and Resarch, Ankara, Türkiye. Email:kartalsibel2011@gmail.com
}

Geliş Tarihi - Received: 01.06.2021

Kabul Tarihi - Accepted: 03.06.2021

Yayımlanma Tarihi - Published: 30.06.2021 
Neslihan, seni bu satırlarda anlatmam imkansız. Bu zamansız gidişin tüm sevdiklerin gibi beni de derinden üzdü, ölüm çok acı. Ne kadar zaman geçerse geçsin seni hiç unutmayacağım. Hep olmak istediğin yerde zeytin ağaçlarının gölgesinde ve esintisinde sana huzurlu uykular diliyorum. Seni çok özlüyorum ve her zaman özleyeceğim. 